\title{
Innovation in judicial services: a study of innovation models in labor courts
}

\author{
Michele Machado \\ Federal University of Goias, Goiânia, Brazil \\ Marcos Sousa \\ Goiano Federal Institute, Federal University of Goias, Goiânia, Brazil \\ Vicente Rocha \\ Federal University of Goias, Goiania, Brazil, and \\ Antonio Isidro \\ University of Brasilia, Brasilia, Brazil
}

\begin{abstract}
Purpose - The purpose of this study is to identify innovation models in the judiciary according to the current integrated theoretical approach for innovation in services.

Design/methodology/approach - This study uses a quantitative approach. The authors collected the data through a questionnaire sent to labor court public servants and judges in a Regional Labor Court in the Midwestern region of Brazil. They performed a principal component analysis to identify the factors to map the innovation models present in the court.

Findings - Two factors were obtained from the results, which describe innovations in processes and services in the court studied. In terms of the examples of innovations cited by the respondents, one may note that those related to information and communications technology are the most remembered, especially the introduction of the electronic lawsuit.

Originality/value - The results can contribute toward a deeper understanding of which vectors of service innovation are affected as well as the nature of the court's underlying structure. Also, the research instrument used allows the identification and analysis of the innovation model for services and thus contributes to its validation.
\end{abstract}

Keywords Service innovation, Public administration, Judicial administration

Paper type Research paper

\section{Introduction}

Innovation is part of the worldwide agenda of the public sector and contributes directly to the modernization of government in terms of facing complex problems such as social inequality, urban violence, mobility, social participation (Bekkers et al., 2011a, 2011b, 2011c)

(C) Michele Machado, Marcos Sousa, Vicente Rocha and Antonio Isidro. Published in Innovation \& Management Review. Published by Emerald Publishing Limited. This article is published under the Creative Commons Attribution (CC BY 4.0) licence. Anyone may reproduce, distribute, translate and create derivative works of this article (for both commercial and non-commercial purposes), subject to full attribution to the original publication and authors. The full terms of this licence may be seen at http://creativecommons.org/licences/by/4.0/legalcode

Innovation in judicial services 
INMR

15,2

and improving judicial performance (Sousa and Guimaraes, 2017). Innovation represents new approaches to public action as well as the art of thinking of and developing ideas and actions in ways that are better than those that have been practiced in public administration in the past (Anttiroiko et al., 2011a, 2011b). There are various typologies of innovation, but these classifications almost always deal with organizational innovations and innovations in processes, marketing, communications or services (Bloch, 2010; OECD, 2005).

Innovation regarding services is one of the types of innovation practiced by the public sector, which is a sector that is a great supplier of services, such as those offered as part of education, health and social assistance policies in Brazil. In these areas, any improvement can have a significant impact on the quality of services owing to the importance that these areas have in terms of public spending (Sousa et al., 2015).

Economics initially considered that services play a secondary role in the economy. Kon (2004) has analyzed the evolution of economic thinking and perceives that the increase in the importance given to the service sector, which has gone from being considered unproductive to being considered complementary. However, it is still given less importance than the industrial sector. Gallouj (2002) also supports this view, arguing that economic theory, with its origins in agriculture and manufacturing, has contributed to the creation of myths, which make the analysis of innovation in services difficult. In the context of the service sector, Gadrey (2001) and Djellal and Gallouj (2005) propose that the measurement of performance in terms of innovation needs to take into consideration a pluralist and multi-criteria view, as well as an adjustment in assumptions.

This statement is also true for the public sector. The public sector is recognized as being important and having a great effect on society (Hauknes, 2005). Therefore, studying innovation in this sector is relevant because it is responsible for the large volume of services offered to citizens, even more so in Brazil, a country in which the State historically has strong participation in the offering of services to society in areas such as education, health, social assistance and retirement. Historically, the public sector worldwide has been the primary source of innovation in organizations, technologies and the generation of innovative ideas (Pollitt, 2011). There are also studies, such as the one made by Earl (2002) in Canada, that demonstrate that some areas of the public sector innovate more than the private sector (Ferreira et al., 2014; Fuglsang and Pedersen, 2011). In any event, there are no doubts about the existence of innovation in the public sector, a fact observed by a large number of studies and publications in many countries, such as the USA (Borins, 2006, 2008) as well as European countries (Bekkers et al., 2011a, 2011b, 2011c; Bommert, 2010; Damanpour and Schneider, 2009; Windrum et al., 2010).

As a part of public services, the judiciary has the role of judging and guaranteeing individual, collective and social rights, solving conflicts between citizens, entities and the State (Brasil, 2013). Given its importance, the innovations adopted and developed by the Brazilian judiciary should be diagnosed and evaluated from a theoretical and an empirical point of view. To identify models of innovation adopted by courts through the theoretical lens of the integrated approach to innovation as defined by the service innovation school of thought (Bekkers et al., 2011a, 2011b, 2011c; Borins, 2008; Damanpour and Schneider, 2009; Gallouj and Iauml, 2002) is what this study seeks. Also, the study seeks to understand the phenomenon of innovation in judicial organizations to fill a gap in this research field given that there have been relatively few studies of innovation in the public sector (Gallouj and Savona, 2010a, 2010b; Howells, 2010), especially in terms of a specific sector of public administration such as the judiciary.

Various typologies and classifications have been formulated to analyze and explain the phenomenon of innovation using mainly the context of industrial organizations as a 
reference (Bloch, 2010; Gallouj and Savona, 2010a, 2010b; OECD, 2005). That is the reason, in identifying innovation in the judiciary in this work, we have chosen to use the models and principles related to innovation in services proposed by Djellal and Gallouj (2005) and Gallouj and Weinstein (1997), which point to the need to characterize the factors that make up the process of creating and delivering services.

This article is divided into five different sections: Section 1 is the introduction and the research question, while Section 2 deals with theoretical references and Section 3 deals with the methodology used in performing this study. Section 4 presents a discussion of the results judicial services obtained and Section 5 contains the study's conclusions.

\section{Theoretical references}

The service sector is so poorly understood that it compromises the analysis of innovation in this sector (Gallouj, 2002, 2007) despite its growing economic importance. This incomprehension has generated myths, which originate from the emphasis given in economic theory to the manufacturing and agricultural sectors. According to Gallouj (2002) these myths are as follows:

- the services sector is unproductive and understood to be residual, peripheral and pathological;

- the services sector is responsible for the increase in unqualified workers with low salaries;

- this sector is not capable of innovating; and

- this sector is, therefore, determined to be unproductive and not capital-intensive.

Innovation theory is still not formalized and established but is rather an amalgam of various areas of economics, management, organizational psychology, cognitive and systems theories, which deal with multiple aspects of innovation (Røste, 2004). Specific studies of innovation in services have become more common recently, but according to Gallouj and Savona (2010a, 2010b), they are still more fragmented and less empirical than studies of technical change. Gallouj (2002) presents the following characteristics of the service sector:

- the difficulty in standardization;

- difficulty in delineating the differences between products and processes;

- skills that are intrinsically linked;

- the difficulty to evaluate performance; and

- lack of clarity in delineating differentiation and innovation.

It seems clear that the challenges that face these innovation studies are great, and in dealing with the public sector, they seem greater still given the characteristics of governments. Also, governments are immersed in institutional environments that are structured with large amounts of norms and regulations, which certainly play a role in the efficiency of providing services (Gallouj and Savona, 2010a, 2010b; Harrisson et al., 2010).

Innovation is of great importance, both for the public and the private sectors (Hartley, 2005), but there are differences between innovation in the private and the public sectors. This is because private sector is oriented toward profits and furthering the interest of owners, and in the public sector, most innovation is required (and legally mandatory) by politicians who seek to serve or impress the electorate (Borins, 2014). There is a belief among researchers that the public sector innovates less than the private sector. However, innovation has always been a part of the public sector and often in a manner in which it is 
INMR

15,2

similar to the private sector (Bekkers et al., 2011b), or even more innovative in some areas, such as the innovations found by Earl (2002) in Canada.

Many researchers have assumed that the object of innovation is to improve the performance of the public sector (Borins, 2014), but this tends to be visible in the private sector where innovation can lead to substantial returns in the form of increased market share, thus leading people to value, promote and invest in innovation. Meanwhile, the public sector has traditionally been characterized by monopolies on the part of the suppliers of products and services, so people in the government have had little incentive to engage and invest in innovation (Kamarck, 2003). However, today in the beginning of the twenty-first century, governments around the world are committed to making efforts to reform government structures and inject the culture of innovation in their bureaucracies (Kamarck, 2003). Such changes are mainly owing to the social pressure placed on the public sector to deliver quality services to their citizens even given the scarcity of resources worldwide (Lewis et al., 2017). One way of encouraging innovative processes is to promote innovation competitions that award public servants who conceive and develop creative projects and actions (Borins, 2006, 2008; Ferreira et al., 2014).

The need for innovation in the public sector can be defined as the search for new ideas and concepts, technologies, techniques and methods, ways, systems and procedures to create significant interactions between the government and society to address new social challenges (Bekkers et al., 2011b). These problems can be faced through various types of innovation, including social innovations that look to develop new mechanisms for interacting, and institutional formats that involve society in the search for solutions to their problems (Harrisson et al., 2010; Windrum et al., 2010).

Many studies have been conducted in a variety of countries such as those that are presented in the book Innovations in Government by Borins (2008). One of the authors (Rizvi, 2008) argues that there is no doubt that innovations have made governments more efficient concerning solving problems and have been efficient relating to costs. This author further emphasize that innovation is central to giving societies the ability to construct the new models of government and governance necessary to face the significant challenges of the twenty-first century. In other words, governments need to reinvent themselves to become more intelligent, flexible and innovative (Rizvi, 2008). Within government organizations, there is a belief that innovation initiatives can make governments better in seeking solutions to problems that they need to resolve.

Innovative people in the public sector, with a vision of the future, share the conviction that there is room for searching for creative ways to solve problems to inspire improvisation, experimentation and risk-taking to innovate within their organizations (Borins, 2014). Creative techniques attempt to focus attention on tacit knowledge and encourage people to make connections using their intrinsic motivations. Motivation is a concept frequently used to illuminate change in the workplace (Glor, 2001). Unlike the private sector, governments do not use much creativity to motivate their workers to develop innovations. In the public sector, workers who are committed to their work feel this way owing to their intrinsic motivation. But governments as organizations do not do much to encourage or induce the intrinsic motivations of their public servants (Glor, 2001), which would be fundamental to the creation and development of innovation in governmental organizations.

Innovation in the public sector is a well-known, continuous and lasting phenomenon (Bekkers et al., 2011a, 2011b), and it persists because individuals launch innovations, innovation incentive programs recognize their work and researchers study them. Prize competitions not only recognize these ideas but also offer opportunities by communicating 
and disseminating their results and furnishing data for researchers to study this phenomenon (Borins, 2014).

However, what can be considered innovation? An initiative constitutes an innovation if it is new to the organization in which it is being implemented (Borins, 2014). Innovations begin as ideas, with professionals coming up with them and the organizational structure supporting them. Innovation is a complex subject and is studied by multiple perspectives of analysis by researchers in various areas of knowledge (Borins, 2014; Damanpour and Schneider, 2009), and the essential question that still needs to be answered is the role that judicial services each identifiable factor plays in supporting innovation. Do these factors influence innovation individually or in combination with other factors? Another critical question is identifying whether innovation is an adaptation or a replication of another innovation (Borins, 2014). Innovations in public administration also clarify value chains regarding how managers promote or facilitate accountability between a government and its citizens (Anttiroiko et al., 2011a, 2011b).

Recently, within the context of the adoption of new technologies by the Brazilian judiciary, there has emerged the figure that Fontainha (2012) calls the "entrepreneurial judge". That figure has rational characteristics in administration derived from the logic of private companies, such as the maximization of profit, productivity analyses and management indicators, performance targets and a focus on the customer (Fontainha, 2007, 2012). There has been a trend toward the professionalization of judicial administration (Fontainha, 2009) and a higher valuing of judges with managerial abilities (Gomes et al., 2016).

The main reference for innovation studies is the Oslo Manual, which contains definitions and indicators. Even though it has gone through several revisions, it still does not appear to address the service sector in great depth (Gadrey et al., 1995; Gallouj, 2002). It has been an especially complicating factor given that innovation analysis and measurement techniques used in the manufacturing context can lead to measurement errors when applied to the service sector (Gallouj, 2002). In addition to the problems of transposing private sectors models to the public sector, there are the following problems: the wide range of users and the multidimensionality of impacts; many of the methods for measuring economic impact are inadequate for the public sector because the effects need to be monetized, which is not always possible; measurements are generally static and processes are dynamic; and quantitative measurements are not always the best ways to measure certain results (Kattel et al., 2013).

The analytic model for innovation specific to the service sector proposed by Gallouj and Weinstein (1997) suggests the existence of skill vectors, which when adapted to the judiciary, consist of the individual skills of the service provider - judges and public servants $[C]$, the skills of the judiciary user $\left[C^{\prime}\right]$, the vector for the service's technical characteristics $[X]$ and the characteristics of the final results of the judicial services provided $[Y]$.

Gallouj and Weinstein (1997) also defined the following models based on innovation in services and an analytic model composed of the following skills:

- radical: relating new components $\left\{\left[C^{\#}\right],\left[C^{\#}\right],\left[X^{\#}\right],\left[Y^{\#}\right]\right\}$ that are different from the previous vectors $\left\{[C],\left[C^{\prime}\right],[X],[Y]\right\}$;

- improvement: related to an improvement in $[Y]$ resulting in improvements in $[C]$ or in $[X]$. This type of innovation does not involve a change in the underlying structure of the vectors;

- incremental: the underlying structure of the vectors $\left\{[C],\left[C^{\prime}\right],[X],[Y]\right\}$ remains the same, but elements in $[X]$ and/or in $[Y]$ are added or substituted; 
INMR

15,2

160

- ad hoc: concept of a new and specific service requested by the customer. In this model, $[Y]$ is altered for a particular problem and this involves alterations in $[C]$ and in intangible elements of $[X]$;

- recombinative: which occurs through the addition of characteristics or the creation of new ones $[Y]$ through a combination or separation of existing services [C]; and

- formalization: related to the standardization of the vector characteristics with the objective of clarifying the behavior between the characteristic and the providing of the service, which involves organizing the system.

In addition to these models, Djellal and Gallouj (2005) propose organizing principles and logic that contribute to the understanding of the configuration of innovation on an organizational level. They consist of the following types of logic:

- extensive or additive: the characteristics that constitute the services, represented by the vector $\left[S_{k}\right][1]$ are added to the main service;

- regressive or eliminatory: occurs with the elimination of $\left[S_{k}\right]$ from the composition of the organization service;

- intensive: a change in one or more components of $[C]$ or $[\gamma][2]$ by addition which may be accompanied by the elimination of some components;

- combinatory: also called architectural, which consists of the association with or disassociation from the corresponding $\left[S_{k}\right],[C]$ and $[\gamma]$.

Innovation in the judiciary has been researched from the following perspectives:

- organizational-managerial, with the application of administrative techniques;

- judicial innovations, with a focus on legal changes and judicial procedures; and

- technological innovations, with a greater number of studies that have investigated the use of information and communications technology (ICT; Sousa and Guimaraes, 2014).

In this study, to fill the gap in empirical studies of innovation in the public sector and to better understand innovation in the judiciary, we have chosen to use the models and principles of service innovation proposed by Djellal and Gallouj (2005) and Gallouj and Weinstein (1997) to identify innovations in the labor courts. Now, we will present our methodological procedures.

\section{Methodological procedures}

To identify the innovation models that have been adopted by the courts, according to the models defined by the integrated approach to innovation in services, this study uses a quantitative approach. We have collected our data through a questionnaire sent to labor court public servants and judges in a Regional Labor Court in the Midwestern region of Brazil.

The population analyzed is made up of public servants and judges of the Regional Labor Court of Goiás. This court is divided into 13 local courts in Goiânia, 4 in Anápolis, 2 in Aparecida de Goiânia, 2 in Rio Verde and 1 in each of the following cities: Caldas Novas, Catalão, Ceres, Formosa, Cidade de Goiás, Iporá, Itumbiara, Jataí, Luziânia, Mineiros, Porangatu, Posse, São Luís de Montes Belos, Uruaçu and Val Paraíso de Goiás. The total numbers of public servants and judges that make up this population and sample are presented in Table I. 


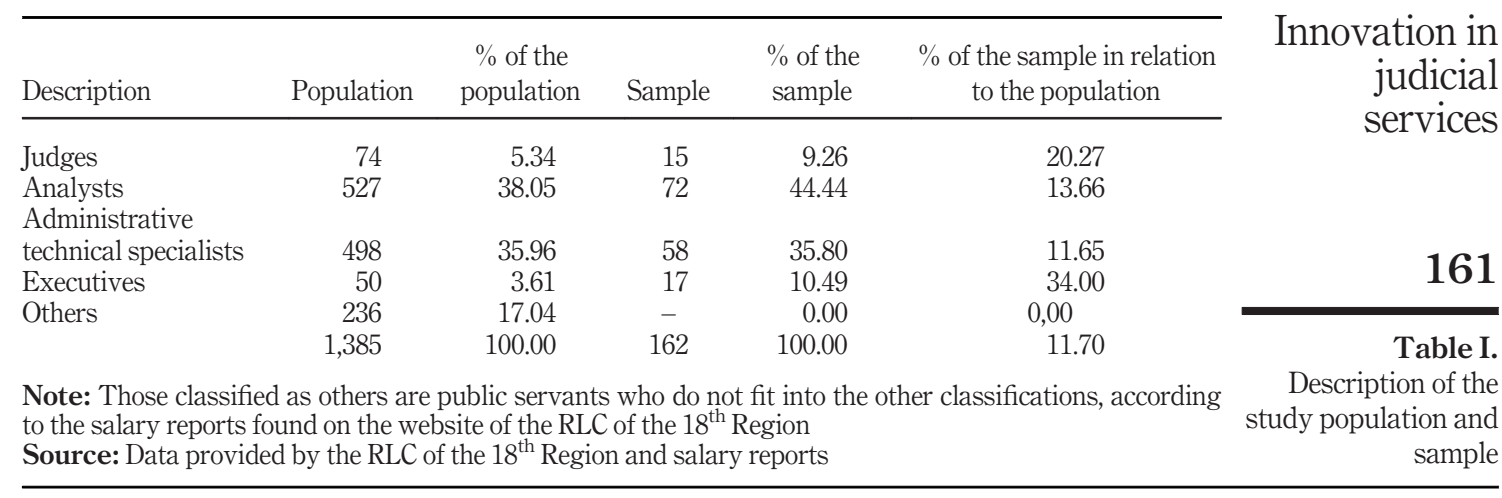

As can be seen in Table I, the population studied is made up of 1,385 public servants and judges of the Labor Court of Goiás. Of these, 204 began filling out the questionnaire, but only 162 respondents finished them. Thus, the study sample is made up of 162 respondents who make up 11.70 per cent of the population.

The questionnaire includes yes/no, multiple choice and scaled closed questions. In scaled questions, individuals determine their degree of acceptance or rejection of a statement. This questionnaire was sent electronically to the emails of public servants and judges who responded by creating a form with the use of the website survey monkey. The email list was obtained through a protocol that was created by administrative process 4073/2013, accepted in July 2013.

The yes/no and multiple choice questions were prepared to extract information about the personal and professional characteristics of the respondents. To analyze this information, we applied descriptive statistical techniques and frequency analysis ( $\mathrm{Chi}^{2}$ and $\mathrm{Phi}$ coefficient tests). The latter was used to identify differences and similarities between the individual and professional patterns of the respondents.

The opinion scale refers to innovation models for services and was prepared in keeping with the works of Gallouj and Weinstein (1997) and Djellal and Gallouj (2005). The statements that make up this scale are presented in Table II.

The statements presented in Table II are related to innovation models for services. They were delivered to the respondents who made their answers from a scale of 0 (totally disagree) to 10 (totally agree), and as a result, this represents the perceptions of the participants in relation to the innovation process.

With these results in hand, we next sought to identify the factors that make it possible to map the innovation models present in the court. To do this, we performed a principal component analysis - PCA. This is a multivariate statistical analysis that provides tools to analyze the structure of the interrelationships between a large number of variables, defining groups of variables that are strongly interrelated, which are known as factors (Hair et al., 2009). Therefore, this allowed us to group the results obtained concerning to this scale into factors, and these provide evidence for the innovation model of the services that are offered by the court.

To apply factor analysis to the principal components, we tested whether this technique is appropriate for this study sample. Thus, we used Bartlett's test of sphericity to verify correlations between the alternatives and then applied the KMO test to infer whether the sample is appropriate for performing factor analysis according to Hair et al. (2009). A perfect fit is equal to 1, that is, the closer the value of KMO to 1, the better the sample's fit is. 


\section{INMR}

15,2

$1 \quad$... developed new services/products offered by the judiciary

$2 \quad$... standardized their services/products, making them more accessible to society

$3 \quad \ldots$ developed new ways of relating to their customers (lawyers, plaintiffs and defendants)

$4 \quad \ldots$ improved the characteristics and/or content of the current services/products, generating new

162

$5 \quad$... combined or recombined various characteristics of current products/services, generating new services/products

$6 \quad$... broadened or suppressed characteristics and/or content of current services/products

$7 \quad \ldots$ introduced new services/products to provide services to society

$8 \quad \ldots$ made changes in internal procedures to improve the providing of services to society

$9 \quad$... changed the way in which services/products are delivered to their customers (lawyers, plaintiffs, defendants and society in general)

$10 \quad$... developed specific solutions for particular problems and demands or judicial processes

$11 \ldots$ improved and/or adopted the technology (equipment, hardware, software) used to deliver its products/services to its customers (lawyers, plaintiffs, defendants and society in general)

Table II.

Statements according to innovation models for services general) by transferring information and knowledge about their services/products

... developed employee skills to deliver its services/products

... improved its managerial model

Source: Prepared based on Gallouj and Weinstein (1997) and Djellal and Gallouj (2005)

We would like to emphasize that the statements in our research instrument, described in Table II, were tested for their reliability. Cronbach's alpha was used to verify this, and it enabled us to infer whether the collected results were robust, that is, if they really represented the opinion of the respondents.

\section{Results and discussion}

This section has been subdivided based on the characteristics of the respondents and the innovation analysis, to provide the best visualization of the personal and professional features of the respondents as well as the innovation process that occurs in the court.

\subsection{Personal and professional characteristics of the respondents}

There are two personal characteristics collected regarding the court's respondents: gender and age group. The results comparing both variables and the symmetry measurements are presented in Table III below:

It is observed in Table III that 48.8 per cent of the respondents are of the female gender, while 51.2 per cent are of the male gender. Also, note that the largest concentrations in terms of age groups for both sexes occur in the age groups of 26 to 35 years and 36 to 45 years, respectively. In analyzing the frequencies of the female sex by age group, we can see that they are different from those of the male gender, giving a $p$-value of 0.0346 when we apply the $\mathrm{Chi}^{2}$ test. Therefore, the participants of the female gender have frequencies per age group that are statistically different from the rates for the male sex even though overall they are concentrated in the 26 to 45 age group.

To delve deeper into our analysis of the respondents, we have chosen to separate the data by position and gender and position and age group. The results are presented in Tables IV (position and gender) and $\mathrm{V}$ (position and age group). 


\begin{tabular}{|c|c|c|c|c|c|c|c|}
\hline \multirow[b]{2}{*}{ Gender } & \multirow[b]{2}{*}{ Up to 25} & \multirow[b]{2}{*}{ From 26 to 35} & \multicolumn{2}{|c|}{ Age group (in years) } & \multirow[b]{2}{*}{56 and over } & \multirow[b]{2}{*}{ Total } & vation in \\
\hline & & & From 36 to 45 & From 46 to 55 & & & \multirow{4}{*}{$\begin{array}{l}\text { judicial } \\
\text { services }\end{array}$} \\
\hline \multicolumn{7}{|l|}{ Female } & \\
\hline Number & 0 & 37 & 26 & 11 & 5 & 79 & \\
\hline Percentage of the total & 0.0 & 22.8 & 16.0 & 6.8 & 3.1 & 48.8 & \\
\hline \multirow{5}{*}{$\begin{array}{l}\text { Male } \\
\text { Number } \\
\text { Percentage of the total } \\
\text { Number } \\
\text { Percentage of the total }\end{array}$} & \multirow{5}{*}{$\begin{array}{l}1 \\
0.6 \\
1 \\
0.6\end{array}$} & \multirow{5}{*}{$\begin{array}{l}33 \\
20.4 \\
70 \\
43.2\end{array}$} & \multirow{5}{*}{$\begin{array}{l}26 \\
16.0 \\
52 \\
32.1\end{array}$} & \multirow{5}{*}{$\begin{array}{l}23 \\
14.2 \\
34 \\
21.0\end{array}$} & \multirow{5}{*}{$\begin{array}{l}0 \\
0.0 \\
5 \\
3.1\end{array}$} & \multirow{5}{*}{$\begin{array}{c}83 \\
51.2 \\
162 \\
100.0\end{array}$} & \multirow{5}{*}{163} \\
\hline & & & & & & & \\
\hline & & & & & & & \\
\hline & & & & & & & \\
\hline & & & & & & & \\
\hline \multicolumn{7}{|c|}{ Symmetry measurements } & \multirow{5}{*}{$\begin{array}{r}\text { Table III. } \\
\text { Gender and age } \\
\text { group of the } \\
\text { respondents }\end{array}$} \\
\hline Test & & & \multirow{4}{*}{$\begin{array}{l}\text { Value } \\
10.37142319 \\
162\end{array}$} & & \multirow{4}{*}{\multicolumn{2}{|c|}{$\begin{array}{c}\text { Approx. sig. } \\
0.0346\end{array}$}} & \\
\hline Pearson's Chi ${ }^{2}$ & & & & & & & \\
\hline Number of valid cases & & & & & & & \\
\hline Source: Study results & & & & & & & \\
\hline
\end{tabular}

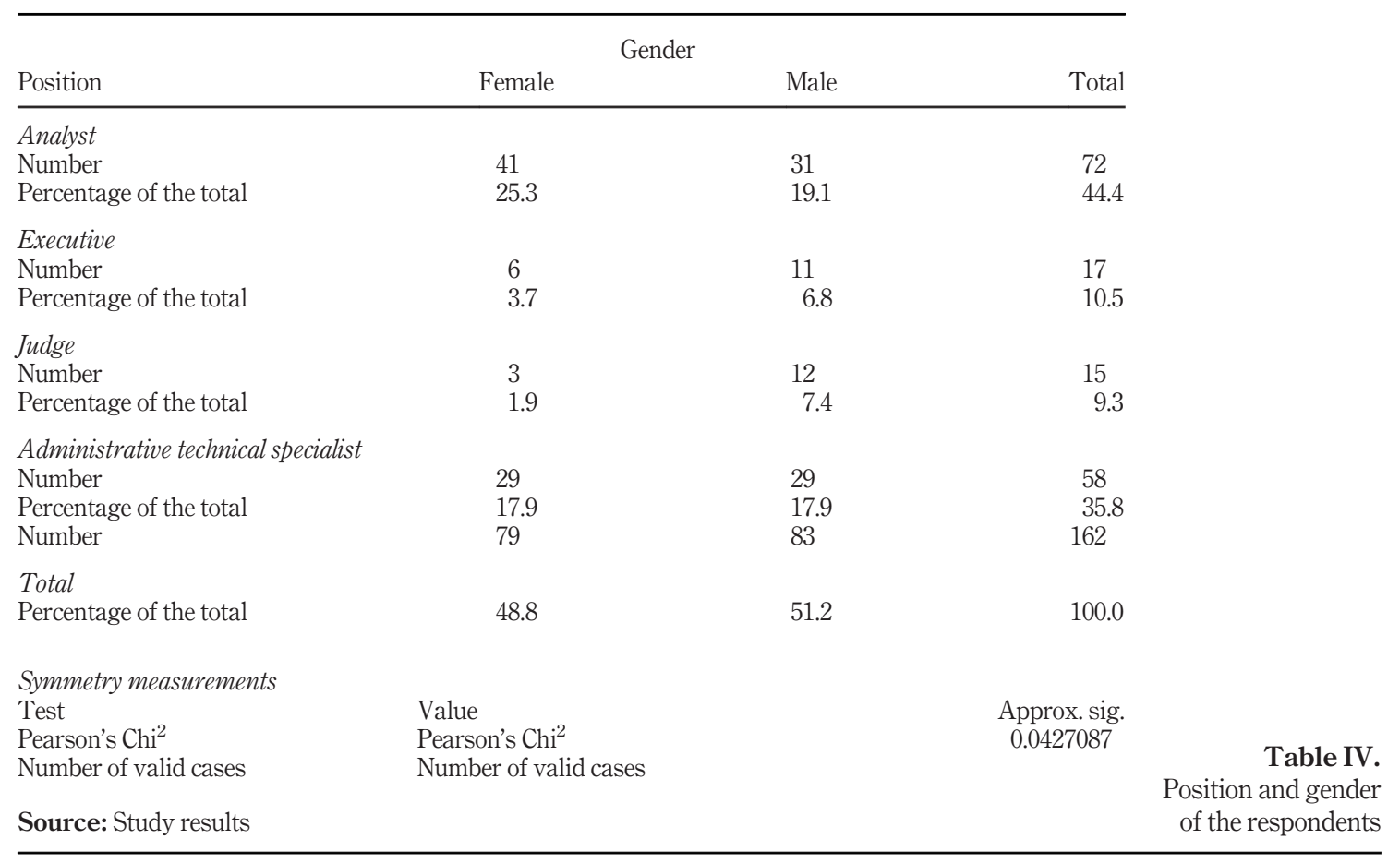


INMR

15,2

164

In analyzing the profile of the participants regarding of their positions and gender, we can see that the frequencies between them have a level of significance of 5 per cent, as demonstrated by the obtained $p$-value of 0.042 . This difference may be observed by the difference in the predominance of analysts of the female gender and the majority of respondents of the male sex with positions as executives and judges.

We can see in Table $\mathrm{V}$ that the frequency of the positions by age group is statistically different with a significance level of 1 per cent. We may also observe in this table that of the 43.2 per cent of the respondents, who are in the 26 to 35 years age group, 25.3 per cent are analysts and 16.0 per cent are administrative technical experts. We can also see that the positions of judges and executives are mainly occupied by professionals above the age of 35 years.

In terms of the professional characteristics of the respondents, we analyzed their frequencies according to position and education, and position and length of service. The results are presented in Tables VI and VII.

Table VI presents the frequency distribution of position and education. It may be verified that the most significant concentration of respondents is found in analysts with a specialization. This position also had respondents with doctorates, the highest form of education. In terms of education, it may be observed that 72.2 per cent of the respondents had a specialization. When the frequency is analyzed in terms of positions and level of education, we may note that in statistical terms, the rates of the respondents by position and education are statistically equal because the $p$-value was found to be 0.126 . Therefore, the level of education relative to the positions of these respondents is statistically equal.

\begin{tabular}{|c|c|c|c|c|c|c|}
\hline \multirow[b]{2}{*}{ Position } & \multicolumn{5}{|c|}{ Age group (in years) } & \multirow[b]{2}{*}{ Total } \\
\hline & Up to 25 & From 26 to 35 & From 36 to 45 & From 46 to 55 & 56 and over & \\
\hline \multicolumn{7}{|l|}{ Analyst } \\
\hline Number & 0 & 41 & 18 & 12 & 1 & 72 \\
\hline Percentage of the total & 0.0 & 25.3 & 11.1 & 7.4 & 0.6 & 44.4 \\
\hline \multicolumn{7}{|l|}{ Executive } \\
\hline Number & 0 & 2 & 6 & 7 & 2 & 17 \\
\hline Percentage of the total & 0.0 & 1.2 & 3.7 & 4.3 & 1.2 & 10.5 \\
\hline \multicolumn{7}{|l|}{ Judge } \\
\hline Number & 0 & 1 & 5 & 9 & 0 & 15 \\
\hline Percentage of the total & 0.0 & 0.6 & 3.1 & 5.6 & 0.0 & 9.3 \\
\hline \multicolumn{7}{|c|}{ Administrative technical specialist } \\
\hline Number & 1 & 26 & 23 & 6 & 2 & 58 \\
\hline Percentage of the total & 0.6 & 16.0 & 14.2 & 3.7 & 1.2 & 35.8 \\
\hline \multicolumn{7}{|l|}{ Total } \\
\hline Number & 1 & 70 & 52 & 34 & 5 & 162 \\
\hline Percentage of the total & 0.6 & 43.2 & 32.1 & 21.0 & 3.1 & 100.0 \\
\hline \multicolumn{7}{|l|}{ Symmetry measurements } \\
\hline \multirow{3}{*}{\multicolumn{2}{|c|}{$\begin{array}{l}\text { Test } \\
\text { Pearson's Chi }{ }^{2} \\
\text { Number of valid cases }\end{array}$}} & \multirow{3}{*}{\multicolumn{3}{|c|}{$\begin{array}{l}\text { Value } \\
38.97855198 \\
162\end{array}$}} & \multirow{3}{*}{\multicolumn{2}{|c|}{$\begin{array}{c}\text { Approx. sig } \\
0.0001\end{array}$}} \\
\hline & & & & & & \\
\hline & & & & & & \\
\hline \multicolumn{7}{|l|}{ Source: Study results } \\
\hline
\end{tabular}

Table V.

Position and age group

Source: Study results 


\begin{tabular}{|c|c|c|c|c|c|c|c|}
\hline Position & $\begin{array}{l}\text { High school/ } \\
\text { technical }\end{array}$ & College & Specialization/MBA & Masters & Doctorate & Total & $\begin{array}{r}\text { judicial } \\
\text { services }\end{array}$ \\
\hline \multicolumn{8}{|l|}{ Analyst } \\
\hline Number & 0 & 12 & 57 & 1 & 2 & 72 & \multirow{5}{*}{165} \\
\hline Percentage of the total & 0.0 & 7.4 & 35.2 & 0.6 & 1.2 & 44.4 & \\
\hline Executive & & & & & & & \\
\hline Number & 1 & 1 & 15 & 0 & 0 & 17 & \\
\hline Percentage of the total & 0.6 & 0.6 & 9.3 & 0.0 & 0.0 & 10.5 & \\
\hline \multicolumn{8}{|l|}{ Judge } \\
\hline Number & 0 & 4 & 10 & 1 & 0 & 15 & \\
\hline Percentage of the total & 0.0 & 2.5 & 6.2 & 0.6 & 0.0 & 9.3 & \\
\hline \multicolumn{8}{|c|}{ Administrative technical specialist } \\
\hline Number & 1 & 19 & 35 & 3 & 0 & 58 & \\
\hline Percentage of the total & 0.6 & 11.7 & 21.6 & 1.9 & 0.0 & 35.8 & \\
\hline \multicolumn{8}{|l|}{ Total } \\
\hline Number & 2 & 36 & 117 & 5 & 2 & 162 & \\
\hline Percentage of the total & 1.2 & 22.2 & 72.2 & 3.1 & 1.2 & 100.0 & \\
\hline \multicolumn{8}{|l|}{ Symmetry measurements } \\
\hline Test & & \multirow{4}{*}{\multicolumn{2}{|c|}{$\begin{array}{l}\text { Value } \\
17.65353253 \\
162\end{array}$}} & & \multirow{4}{*}{\multicolumn{2}{|c|}{$\begin{array}{c}\text { Approx. sig. } \\
0.1266\end{array}$}} & \\
\hline Pearson's Chi ${ }^{2}$ & & & & & & & Position and \\
\hline Number of valid cases & & & & & & & education of \\
\hline Source: Study results & & & & & & & respondents \\
\hline
\end{tabular}

Concerning the length of service of the respondents, we can see that 48.1 per cent of them have had up to 5 years of service in the court, which indicates a new corps of public servants. This may be owing to the realization of recent competitive exams for analysts and administrative technical specialists given that 27.2 per cent of all respondents with less than 5 years of service are analysts and 21 per cent administrative technical specialists. In analyzing the frequency of positions by the length of service, we can see that they are statistically different, at a 1 per cent level of significance, with a $p$-value found to be 0.000 . Thus, we can infer that the length of service among positions is statistically different.

The demographic analysis of the respondents makes it possible to infer that the respondents are quite diversified, and therefore, we have a heterogeneous sample of the court judge and public servant population, which, thus, contributes to the validity of the mapping of the innovation models, and will be discussed in the next subsection.

\subsection{Innovation models}

To study innovation in the court, we are using the models of Djellal and Gallouj (2005) and Gallouj and Weinstein (1997), which come from the consolidated theory of innovation in services, making it possible to construct the 14 statements presented in the methodology section.

The number of factors defined is based on the results of eigenvalues, also known as latent root criteria, superior to 1 . Here, only the components - factors - with eigenvalues greater than 1 are considered significant (Hair et al., 2009). This measurement may be observed in Figure 1, which presents the number of factors to be extracted through a scree plot. 


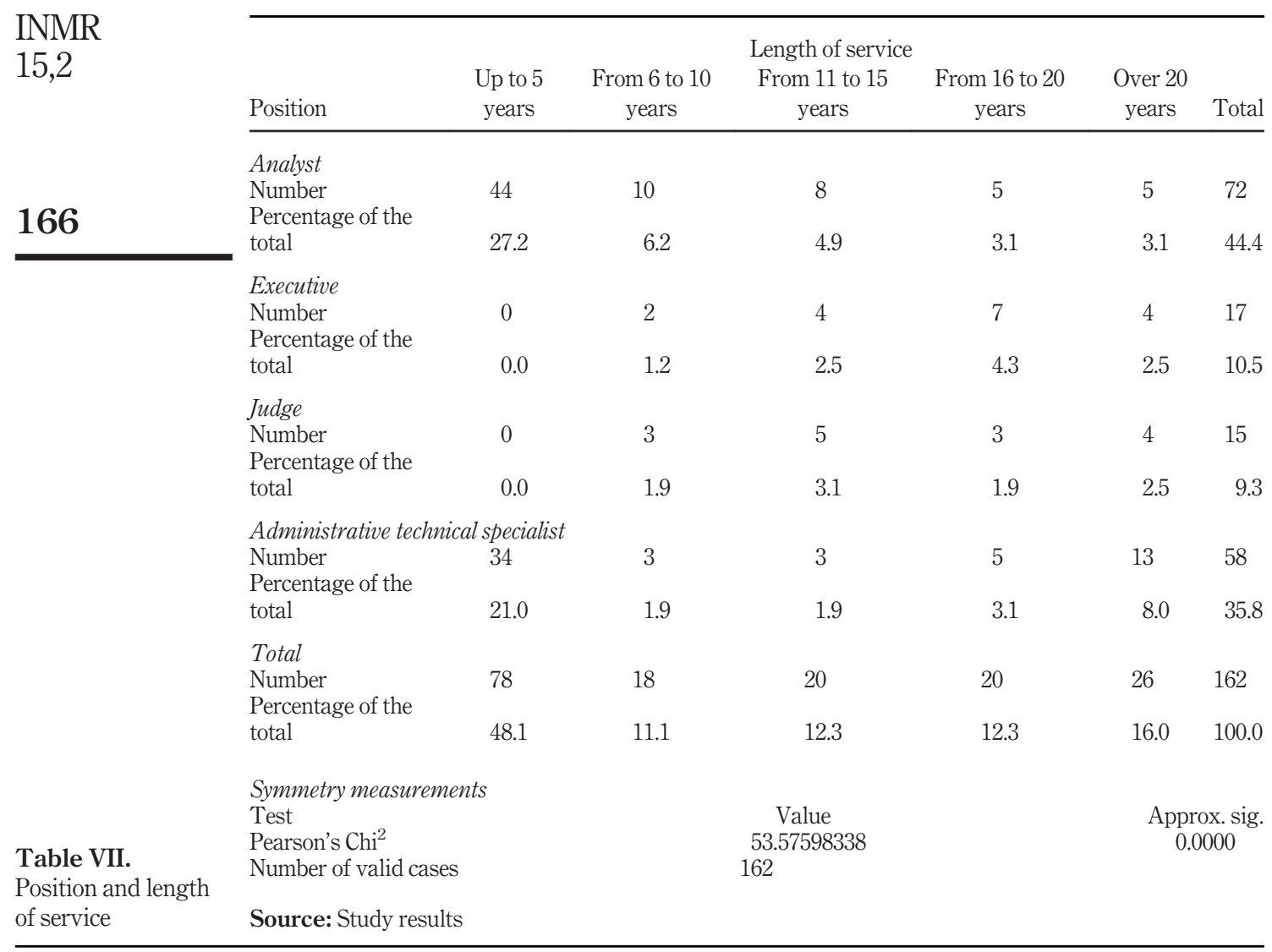

In analyzing Figure 1, we can perceive that two factors have been extracted with eigenvalues superior to 1 , the first presenting a value of 8.407, and the second presenting a value of 1.154 , which together manage to explain 68.29 per cent of the total variation of the data. With the initial results of the factor analysis and the use of the principal components, the factors obtained were rotated by the varimax method, a procedure that facilitates the interpretation of their factor weights. The results of the factor weights with the values of the commonalities are presented in Table VIII.

As demonstrated in Table VIII, given that the communalities (h2) are greater than 0.40, representing factor stability, there is, therefore, no need to exclude any statement. Testing the stability of the encountered factors, we examined the reliability of the obtained results, and found values of Cronbach's alpha greater than 0.90 for these two factors. This result means that they possess internal consistency, with values greater than 0.70 , which according to Hair et al. (2009), is the lower limit of acceptable values.

Two factors were obtained that typify innovation in court processes/services. Naming the factors may seem an arbitrary task, but considering the innovation model for services and the degree of change in the underlying structure, the first factor was named "Process and/or Organizational Innovations" and the second factor was named "Service Innovations". 


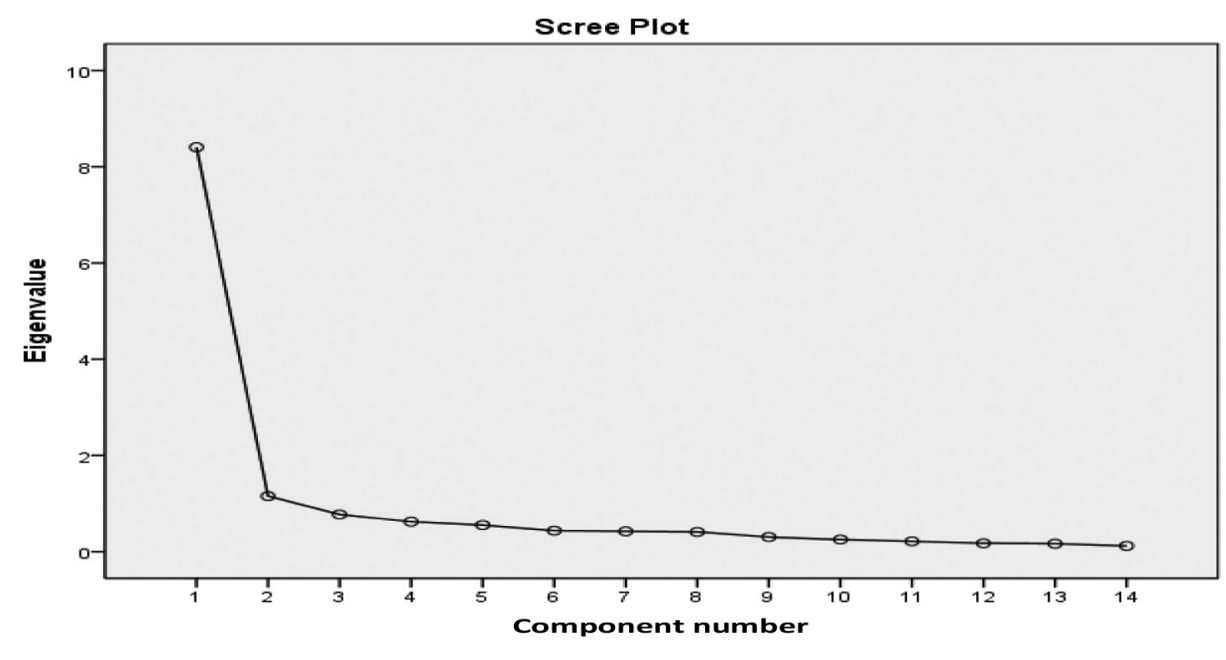

Source: Study results

The factor solutions found showed that the items were grouped based on the locus of the innovation, even though the supporting literature speaks in terms of an innovation's degrees of novelty or underlying changes. Thus, it may be noted that in the context of the present study, the innovation models laid out by Djellal and Gallouj (2005) and Gallouj and Weinstein (1997) combine to provide the locus or object of innovation (services, work processes and organizational elements, among others).

The "Process and/or Organizational Innovation" factor grouped together the statements that deal with innovation in terms of the formalization and standardization of procedures; the improvement of processes; the characteristics of materials, seeking the best way to provide services to society; improvements in employee skills; the improvement and adoption of new technical components; and lastly, managerial improvements, an item that fits into the six models of Gallouj and Weinstein (1997), as well as being an organizational innovation from the point of view of Schumpeter.

The "Service Innovation" factor groups together statements that are more strongly related to change in the underlying structure of services, whether in the form of introducing new components, adding new characteristics or creating new services through a combination or separation of existing items or adding or substituting elements in $[\mathrm{X}]$ and/or [Y].

Therefore, according to this study's results, innovation in court services can be classified into two types, the first related to the government body's processes and organizational elements and the second related to changes in services. Given that the public sector cannot provide financial compensation for innovative initiatives (Borins, 2001), we have identified acts of the institutionalization of innovation as well as more abrupt changes. This result is consistent with the thinking that the public sector does innovate and not infrequently it is an early adopter of new technology (Borins, 2014; Salazar and Holbrook, 2004) and incremental as well as radical innovations do occur as identified by research dealing with the federal public sector (Ferreira et al., 2015).

In addition to mapping the nature of innovation in judicial services, we asked the study participants to provide examples of court innovations to understand which innovations are considered relevant by the users. The results are described in Table IX.
Innovation in judicial services

Figure 1.

Scree plot-number of determined factors 


\section{INMR \\ 15,2}

\begin{tabular}{|c|c|c|c|c|}
\hline $\begin{array}{l}\text { Factor } \\
\text { no. }\end{array}$ & Statements & $\begin{array}{l}\text { Process and/or } \\
\text { organizational } \\
\text { innovations }\end{array}$ & $\begin{array}{c}\text { Service } \\
\text { innovations }\end{array}$ & h2 \\
\hline 1 & $\begin{array}{l}\ldots \text {.. standardized their services/products, make them } \\
\text { more accessible to society }\end{array}$ & 0.673 & 0.402 & 0.614 \\
\hline 1 & $\begin{array}{l}\text {... improved the characteristics and/or content of the } \\
\text { current services/products, generating new services/ } \\
\text { products }\end{array}$ & 0.738 & 0.41 & 0.713 \\
\hline 1 & $\begin{array}{l}\text {... made changes in internal procedures to improve } \\
\text { the providing of services to society }\end{array}$ & 0.699 & 0.356 & 0.615 \\
\hline 1 & $\begin{array}{l}\text {.. developed specific solutions for particular } \\
\text { problems and demands or judicial processes }\end{array}$ & 0.836 & 0.274 & 0.774 \\
\hline 1 & $\begin{array}{l}\text {... improved and/or adopted the technology adopted } \\
\text { (equipment, hardware, software) used to deliver its } \\
\text { products/services to its customers (lawyers, } \\
\text { plaintiffs, defendants and society in general) }\end{array}$ & 0.679 & 0.28 & 0.539 \\
\hline 1 & $\begin{array}{l}\text {... changed the behavior of their customers (lawyers, } \\
\text { plaintiffs, defendants and society in general) by } \\
\text { transferring information and knowledge about their } \\
\text { services/products }\end{array}$ & 0.547 & 0.527 & 0.577 \\
\hline 1 & $\begin{array}{l}\text {... developed employee skills to deliver its services/ } \\
\text { products }\end{array}$ & 0.753 & 0.345 & 0.687 \\
\hline 1 & ... improved its management model & 0.808 & 0.273 & 0.727 \\
\hline 2 & $\begin{array}{l}\text {... developed new services/products offered by the } \\
\text { judiciary }\end{array}$ & 0.217 & 0.756 & 0.619 \\
\hline 2 & $\begin{array}{l}\text {... developed new ways of relating to their customers } \\
\text { (lawyers, plaintiffs and defendants) }\end{array}$ & 0.345 & 0.81 & 0,775 \\
\hline 2 & $\begin{array}{l}\text {... combined or recombined various characteristics } \\
\text { of current products/services and generating new } \\
\text { services/products }\end{array}$ & 0.464 & 0.724 & 0.739 \\
\hline 2 & $\begin{array}{l}\text {... broadened or suppressed characteristics and/or } \\
\text { content of current services/products }\end{array}$ & 0.346 & 0.806 & 0.769 \\
\hline 2 & $\begin{array}{l}\text {... introduced new services/products to provide } \\
\text { services to society }\end{array}$ & 0.345 & 0.811 & 0.777 \\
\hline 2 & $\begin{array}{l}\text {... changed the way in which services/products are } \\
\text { delivered to their customers (lawyers, plaintiffs, } \\
\text { defendants and society in general) }\end{array}$ & 0.4 & 0.69 & 0.636 \\
\hline Cronba & alpha & 0.921 & 0.92 & \\
\hline
\end{tabular}

Table VIII.

Note: Italics are used to differentiate the two factors

communalities

Source: Study results

Of the examples cited by the participants, the one that has the highest profile is the electronic lawsuit. The creation of the electronic lawsuit was determined by Law 11,419 of 2006. In this particular court, the implementation of the electronic lawsuit occurred in January 2011, which is why it developed its program is called the Judicial Administration System (SAJ), whose preparation was determined by Ordinance TRT $18^{\mathrm{a}} \mathrm{GP} / \mathrm{DG} \mathrm{N}^{\circ} 143$ of June 21, 2007.

The Superior Council of Labor Justice, through Resolution $\mathrm{n}^{\circ}$ 94, of March 23, 2012, determined that all of the Regional Labor Courts would use the PJE (Electronic Lawsuit) system, therefore substituting all of the previous programs. In the results of Table IX, we can observe that 13.6 per cent of the participants had criticisms regarding this system, including its implementation, which has presented errors given that it is not as mature as the system developed by the local court, as well as its inability to handle particular characteristics of the 


\begin{tabular}{lcc}
\hline Description & Frequency & \% of the respondents \\
\hline Electronic lawsuit - PJE & 117 & 72.2 \\
Electronic lawsuit - SAJ & 91 & 56.2 \\
Sisdoc & 23 & 14.2 \\
Criticism of the PJE & 22 & 13.6 \\
Others & 20 & 12.3 \\
E-petition & 13 & 8.0 \\
Human resources management & 13 & 8.0 \\
Digital publishing - magazines, publications and certificates & 10 & 6.2 \\
Conciliation & 8 & 4.9 \\
Strategic planning & 7 & 4.3 \\
Electronic letters of request & 6 & 3.7 \\
New equipment & 4 & 2.5 \\
Attachment of property system & 3 & 1.9 \\
Greater participation of the plaintiff & 3 & 1.9
\end{tabular}

Notes: The description also contemplates items presented with less frequency such as: Security management; Standardization of routines; Digital mail pouch; Social/environmental campaigns; Long distance and permanent auditing; Creation of new courts; Electronic communication; Access to information; Agility in the emission of permits and licenses; Itinerant courts; New program of judicial calculations; Customer service; New court installations

Source: Study results

Table IX. Examples of innovation respondents

court. Therefore, even though it is considered an innovation, the flexibility of the PJE needs to be improved to adapt to the necessities of the courts that use this system.

The innovations described in Table IX are still consistent with the models, logic and organizing principles of Djellal and Gallouj (2005) and Gallouj and Weinstein (1997), because they present the following:

- radical innovation processes, such as the electronic lawsuit, Sisdoc (Protocol System for Physical and Electronic Documents), e-petition (Integrated Protocol and Workflow System for Electronic Documents) and electronic letters of request, all of which changed the services developed and provided by the court;

- innovations in employee skills through human resources programs;

- innovations in terms of improvements, formalizations, incremental changes and/or additions in the adoption of conciliation, itinerant courts, attachment of property system, digital publishing of information and certificates, the adoption of strategic planning, standardization of routines, access to information, electronic communication, creation of new courts, new court installations and greater participation by the plaintiff; and

- the adoption of new equipment for the implementation of the technologies used.

The main innovations that have been adopted and developed according to the respondents' perceptions are related to ICTs, which is in keeping with the empirical literature concerning innovation in the judiciary (Sousa and Guimaraes, 2014). According to Rooze (2010), the introduction of ICTs in the management of lawsuits has led to an increase in efficiency, access to justice, a reduction of time, transparency and an improvement in control practices. Along the same lines, Soares and Sviatschi (2010) verified that computerization has helped the resolution of lawsuits in Costa Rica. On the other hand, negative impacts have also been reported in terms of electronic lawsuits; for example, the adoption of the electronic system may initially lead to more printing and rework (Sousa and Guimaraes, 2017). 
INMR

15,2
The present study analyzes innovations in the public sector, specifically the judiciary, classifying them into models and contributes to answering theoretically and empirically the relationship between innovation and the vectors of the studied model. As the question of whether there is innovation in the service sector has already been positively affirmed by studies such as Sundbo (1997) in Denmark, the present study has sought to answer the question of the relationship between the vectors of the service innovation model and to characterize the models of innovation found in judicial organizations.

\section{Conclusions}

To identify the innovation models used in the judiciary according to the integrated approach to current innovation theory for services innovation, we have used a questionnaire sent to a sample of 162 public servants and judges, who represent 11.70 per cent of the population.

Two factors were obtained from our results, which describe innovations in processes and services in the organization studied. The results show that according to the study participants, the perception of the locus of innovation (services, process, managerial model, etc.) predominates compared to the service innovation models found in the literature. Our results, thus, suggest that in public organizations, the degree of novelty (the focus of the innovation), even though it is vital in managing information, is conditioned by the object or locus of the efforts to make changes and improvements in organizations. In other words, we can infer that people pay more attention to what innovations generate in terms of change and impact than how new they are.

In terms of the examples of innovations cited by the respondents, we may note that those related to ICTs are the most remembered, especially the introduction of the electronic lawsuit. However, given the differences between the system developed by the court itself and the PJE system that has substituted it, by the requirement of the National Council of Justice (CNJ), criticisms have been leveled at the new system. Therefore, despite being considered an innovation, the PJE could improve to adapt to the individual needs of the courts that use this system. We did not find innovations related to regressive logic or elimination.

Furthermore, according to the examples cited by the respondents, we have verified that these innovations can be interpreted in light of the models, logic and organizing principles developed by Djellal and Gallouj (2005) and Gallouj and Weinstein (1997). Therefore, we conclude that the innovation models, as well as the logic and organizing principles studied, can contribute to a deeper understanding of the changes in the explicatory innovation vectors and the changes in the underlying structure of the vectors themselves. The research instrument used allows the identification and analysis of the innovation model for services and, thus, contributes to its validation.

Future studies could contemplate a more detailed analysis of the models of innovation, as well as the antecedents, consequences, limitations and facilitators of the innovations adopted and developed by the judiciary. Using this research instrument in other judicial and public administration organizations as well as private sector organizations would help evaluate the robustness of this tool through a more heterogeneous application. The electronic lawsuit, the main observed innovation, also needs to be investigated in greater depth, from the point of view of internal processes as well as the users. We also suggest the adoption of other methodologies and theories, which will make it possible to investigate different categories and dimensions that explain the phenomenon of innovation in public services. 


\section{Notes}

Innovation in

1. In the judiciary, we can cite examples such as conflict resolution, the transport of processes, banking payment and receipt services, management and accounting services.

2. The vector $[\gamma]$ is composed of $\{[M],[I],[K],[R]\}$, where $M$ is material operations; $I$ informational operations; $K$ methodological operations; and $R$ relational operations. A better description may be found in (Djellal and Gallouj, 2005).

\section{References}

Anttiroiko, A.V., Bailey, S.J. and Valkama, P. (Eds) (2011a), "Innovations in public governance in the western world", Innovations in Public Governance, IOS Press, Amsterdam.

Anttiroiko, A.V., Bailey, S.J., Valkama, P. and ebrary Inc. (2011b), "Innovations in public governance", in Anttiroiko, A.V., Bailey, S.J. and Valkama, P. (Eds), Innovation and the Public Sector, IOS Press, Amsterdam.

Bekkers, V., Edelenbos, J. and Steijn, B. (Eds) (2011a), "An innovative public sector? Embarking on the innovation journey", Innovation in the Public Sector: Linking Capacity and Leadership, 1st ed., Palgrave Macmillan, New York, NY, p. 259.

Bekkers, V., Edelenbos, J. and Steijn, B. (Eds) (2011b), Innovation in the Public Sector: Linking Capacity and Leadership, Palgrave Macmillan, Hampshire.

Bekkers, V., Edelenbos, J. and Steijn, B. (2011c), Linking Innovation to the Public Sector: Contexts, Concepts and Challenges, Palgrave Macmillan, New York, NY.

Bloch, C. (2010), Copenhagen Manual: Towards a Conceptual Framework for Measuring Public Sector Innovation, MEPIN, Copenhagen.

Bommert, B. (2010), "Collaborative innovation in the public sector", International Public Management Review, Vol. 11 No. 1, pp. 15-33.

Borins, S. (2001), "Encouraging innovation in the public sector", Journal of Intellectual Capital, Vol. 2 No. 3, pp. 310-319.

Borins, S. (Ed.) (2006), The Challenge of Innovating in Government, 2nd ed., IBM Center for The Business of Government, Arlington.

Borins, S. (Ed.) (2008), Innovations in Government: Research, Recognition, and Replication, 1st ed., Brookings Institution Press, Washington.

Borins, S. (2014), The Persistence of Innovation in Government, Brookings Institution Press/Ash Center, Washington.

Damanpour, F. and Schneider, M. (2009), "Characteristics of innovation and innovation adoption in public organizations: assessing the role of managers", Journal of Public Administration Research and Theory, Vol. 19 No. 3, pp. 495-522.

Djellal, F. and Gallouj, F. (2005), "Mapping innovation dynamics in hospitals", Research Policy, Vol. 34 No. 6, pp. 817-835, available at: https://doi.org/10.1016/j.respol.2005.04.007

Ferreira, V.D.R.S., Najberg, E., Ferreira, C.B., Barbosa, N.B. and Borges, C. (2014), "Inovação em serviços de saúde no brasil: análise dos casos premiados no concurso de inovação na administração pública federal”, Revista De Administração Pública, Vol. 48 No. 5, pp. 1207-1227.

Earl, L. (2002), Innovation and Change in the Public Sector: A Seeming Oxymoron, Statistics Canada.

Ferreira, V.D.R.S., Tete, M.F., Silva Filho, A.I. and Sousa, M.D.M. (2015), "Inovação no setor público federal no brasil na perspectiva da inovação em serviços", Review of Administration and Innovation-Rai, Vol. 12 No. 4, pp. 99-118.

Fontainha, F.D.C. (2007), "Informatização da vida e dos tribunais no brasil", Revista Direito Gv, Vol. 7 No. 1, pp. $57-74$. 
INMR

15,2

Fontainha, F.D.C. (2009), “A informatização do processo: do acesso à administração da justiça”, Revista Da Seção Judiciaria Do Rio De Janeiro, Vol. 16 No. 26, pp. 57-69.

Fontainha, F.D.C. (2012), Juizes Empreendedores: Um Estudo a Partir Da Informatização Dos Tribunais Brasileiros, Editora Lumen Juris, Rio de Janeiro.

Fuglsang, L. and Pedersen, J.S. (2011), "How common is public sector innovation and how similar is it to private sector innovation?”, in Bekkers, V., Edelenbos, J. and Steijn, B. (Eds), Innovation in the Public Sector: Linking Capacity and Leadership, Palgrave Macmillan, New York, NY, p. 259.

Gadrey, J. (2001), "Emprego, produtividade e avaliação do desempenho dos serviços", in Salerno, M.S. (Ed.), Relação De Serviço: Produção e Avaliação, Editora SENAC, São Paulo, pp. $23-65$.

Gadrey, J., Gallouj, F. and Weinstein, O. (1995), "New modes of innovation: how services benefit industry", International Journal of Service Industry Management, Vol. 6 No. 3, pp. 4-16.

Gallouj, F. (2002), "Innovation in services and the attendant old and new myths", The Journal of SocioEconomics, Vol. 31 No. 2, pp. 137-154.

Gallouj, F. (2007), "Economia da inovação: Um balanço dos debates recentes", in Bernardes, R. and Andreassi, T. (Eds), Inovação Em Serviços Intensivos Em Conhecimento, Saraiva. São Paulo, pp. 3-27.

Gallouj, F. and Iauml (2002), "Innovation in services and the attendance old and new myths", Journal of Socio-Economics, Vol. 31 No. 2, p. 137.

Gallouj, F. and Savona, M. (2010a), "Towards a theory of innovation in services: a state of the art", in Gallouj, F. and Djellal, F. (Eds), Handbook of Innovation and Services: A Multi-Disciplinary Perspective, Edward Elgar Publishing. Cheltenham, pp. 27-48.

Gallouj, F. and Savona, M. (2010b), "Towards a theory of innovation in services”, A State of the Art. in Research Policy, Vol. 15, pp. 161-173.

Gallouj, F. and Weinstein, O. (1997), "Innovation in services", Research Policy, Vol. 26 Nos 4/5, pp. 537-556.

Glor, E.D. (2001), "Key factors influencing innovation in government", The Innovation Journal: The Public Sector Innovation Journal, Vol. 6 No. 2, pp. 1-20, available at: https://doi.org/10.1.1.197.4807

Gomes, A.D.O., Guimaraes, T.A. and Souza, E.C.L. (2016), "Judicial work and judges' motivation: the perceptions of brazilian state judges", Law and Policy, Vol. 38 No. 2, pp. 162-176.

Hair, J.F.J., Black, W.C., Babin, B.J., Anderson, R.E. and Tatham, R.L. (2009), Análise Multivariada De Dados, 6th ed., Bookman, Porto Alegre.

Harrisson, D., Klein, J.L. and Browne, P.L. (2010), "Social innovation, social enterprise and services", in Gallouj, F. and Djellal, F. (Eds), The Handbook of Innovation and Services, Edward Elgar Publishing, Cheltenham, p. 822.

Hartley, J. (2005), "Innovation in governance and public services: past and present", Public Money \& Management, Vol. 25, pp. 1-2734, available at: https://doi.org/10.1111/j.1467-9302.2005.00447.x

Hauknes, J. (2005), Some Thoughts about Innovation in the Public and Private Sector Compared, Publin/ NIFU/STEP, Oslo.

Howells, J. (2010), Services and innovation and service innovation: new theoretical directions", in Gallouj, F. and Djellal, F. (Eds), Handbook of Innovation and Services: A Multi-Disciplinary Perspective, Edward Elgar Publishing, Cheltenham, pp. 68-83.

Kamarck, E.C. (2003), Government Innovation around the World, Washington.

Kattel, R., Cepilovs, A., Drechsler, W., Kalvet, T., Lember, V. and Tõnurist, P. (2013), Can We Measure Public Sector Innovation? a Literature Review, Brussels.

Kon, A. (2004), Economia De Serviços: Teoria e Evolução No Brasil, Elsevier, São Paulo.

Lewis, J.M., Ricard, L.M. and Klijn, E.H. (2017), "How innovation drivers, networking and leadership shape public sector innovation capacity", International Review of Administrative Sciences, pp. 1-20, available at: https://doi.org/10.1177/0020852317694085 
OECD (2005), "Oslo manual: guidelines for collecting and interpreting innovation data", Manual, 3rd ed., Oslo, p. 162.

Pollitt, C. (2011), "Innovation in the public sector: an introductory overview", in Bekkers, V., Edelenbos, J. and Steijn, B. (Eds), Innovation in the Public Sector: linking Capacity and Leadership, 1st ed., Palgrave Macmillan, New York, NY, p. 259.

Rizvi, G. (2008), "Innovations in government: serving citizens and strengthening democracy", in Borins, S. (Ed.), Innovations in Government, 1st ed., Brookings Institution Press, Washington, p. 231.

Rooze, E.J. (2010), "Differentiated use of electronic case management systems", International Journal for judicial services Court Administration, Vol. 3 No. 1, pp. 50-60.

Røste, R. (2004), Studies of Innovation in the Public Sector, a Literature Review (D8 No. 2), Oslo.

Salazar, M. and Holbrook, A. (2004), "A debate on innovation surveys", Science and Public Policy, Vol. 31 No. 4, pp. 254-266.

Soares, Y. and Sviatschi, M.M. (2010), The Impact of Modernization on Court Efficiency in Costa Rica (No. WP/OVE 06/10), Washington.

Sousa, M.D.M., Ferreira, V. d RS., Najberg, E. and Medeiros, J.J. (2015), "Portraying innovation in the public service of Brazil: frameworks, systematization and characterization", Revista De Administração, Vol. 50 No. 4, pp. 460-476, available at: https://doi.org/10.5700/rausp1213

Sousa, M.D.M. and Guimaraes, T.A. (2014), "Inovação e desempenho na administração judicial: desvendando lacunas conceituais e metodológicas”, Revista de Administração E Inovação, Vol. 11 No. 2, pp. 321-344, available at: https://doi.org/10.5773/rai.v11i2.1373

Sousa, M.D.M. and Guimaraes, T.A. (2017), "The adoption of innovations in brazilian labor courts from the perspective of judges and court managers", Revista De Administração, Vol. 52 No. 1, pp. 103-113, available at: https://doi.org/http://dx.doi.org/10.1016/j.rausp.2016.09.008

Sundbo, J. (1997), "Management of innovation in services”, The Service Industries Journal, Vol. 17 No. 3, pp. 432-455.

Windrum, P., García-Goñi, M. and Fairhurst, E. (2010), "Innovation in public health care: diabetes education in the UK", in Gallouj, F. and Djellal F. (Eds), Handbook of Innovation and Services: A Multi-Disciplinary Perspective, Edward Elgar Publishing, Cheltenham, pp. 129-152.

\section{Further reading}

Gallouj, F. and Djellal, F. (Eds) (2010), "The innovation gap and the performance gap in the service economies: a problem for public policy", Handbook of Innovation and Services: A MultiDisciplinary Perspective, Edward Elgar Publishing, Cheltenham, pp. 653-678.

\section{Corresponding author}

Marcos Sousa can be contacted at: marcos.moraes@ifgoiano.edu.br

For instructions on how to order reprints of this article, please visit our website: 